\title{
Prescapular Lymph Node
}

National Cancer Institute

\section{Source}

National Cancer Institute. Prescapular Lymph Node. NCI Thesaurus. Code C77654.

A lymph node located in front of the shoulder. 